UDC $66.047 .4 / .5$

\author{
O.S. Ivashchuk, V.M. Atamanyuk, R.A. Chyzhovych, S.S. Kiiaieva, R.R. Zherebetskyi, \\ I.B. Sobechko
}

\title{
PREPARATION OF AN ALTERNATE SOLID FUEL FROM ALCOHOL DISTILLERY STILLAGE
}

\author{
Lviv Polytechnic National University, Lviv, Ukraine
}

\begin{abstract}
The article describes preparation of an alternative solid fuel from corn alcohol distillery stillage, which is the waste of the alcohol industry. We determined the calorific values of the dried alcohol distillery stillage and experimental briquettes, which were made of it by pressing at high pressure and temperature. The average value of the higher calorific value of the dried alcohol distillery stillage is $19545 \mathrm{~kJ} \mathrm{~kg}^{-1}$, while this value for the produced briquettes is in the range of 22445 to $26594 \mathrm{~kJ} \mathrm{~kg}^{-1}$. The established calorific values exceed those of analogues, which are widely used for the producing of alternative solid fuels (miscanthus and energy willow). Solid fuel prepared from corn alcohol distillery stillage can be used both in a solid form and in a dried one. The proposed method for preparation of the solid fuel allows providing additional utilization of alcohol distillery stillage and rational use of secondary raw materials of alcohol production.
\end{abstract}

Keywords: alcohol distillery stillage, secondary raw materials, solid fuel, briquette, calorific value.

DOI: $10.32434 / 0321-4095-2022-140-1-54-59$

\section{Introduction}

The alcohol distillery stillage of grain origin is a by-product of the food industry, which is formed in large quantities in the production of ethyl alcohol. Secondary use of alcohol distillery stillage is difficult due to its short storage time [1].

To increase the storage time, the alcohol distillery stillage requires a drying stage [2], for example by the filtration method, which has previously shown its effectiveness in reducing the moisture content of dispersed raw materials $[1,3,4]$.

An alternative and extremely promising method of using secondary raw materials with natural fibers is the production of solid fuel briquettes [5]. Fuel pellets are an environmentally friendly source of energy used in municipal energy for heating residential buildings and technical premises. The energy required to produce pellets is about $20 \%$ of all energy production consumption [6].

The main materials for the production of solid fuel briquettes are fast-growing trees and perennial grasses. The advantages of this group of plants are their high growth rate, which allows producing large volumes of raw materials and does not require large areas of cultivation. Such plants include energy willow, miscanthus and switch-grass [3]. It is also becoming common to use crop wastes (usually sunflower and corn) to produce pellets [6].

The process of converting vegetable raw materials into solid fuel briquettes is characterized by the initial compaction of the material by reducing the free volume available in the raw material. As a result of increasing the pressure of the pressing process, there are not only elastic but also plastic deformations. This leads to an increase in the forces of intermolecular interaction between the particles, and, consequently, improves the adhesion of the material and increases the strength. The pressing process is carried out at a pressure of $100-200 \mathrm{MN} / \mathrm{m}^{2}$ for successful formation of solid fuel briquettes [7].

Briquetting of vegetable raw materials can be carried out with the use of a binder material or without it. In the case of its use, the density of the obtained samples will be higher, which requires more energy to form a briquette. In the case of briquetting without the additional use of a binder material, the binding of vegetable raw materials is due to the lignin present in the material itself. At temperatures close to $170-200^{\circ} \mathrm{C}$ and high pressure [5], lignin turns into a liquid state and is distributed throughout the

(C) O.S. Ivashchuk, V.M. Atamanyuk, R.A. Chyzhovych, S.S. Kiiaieva, R.R. Zherebetskyi, I.B. Sobechko, 2022

O.S. Ivashchuk, V.M. Atamanyuk, R.A. Chyzhovych, S.S. Kiiaieva, R.R. Zherebetskyi, I.B. Sobechko 
volume of raw materials. After some time, the briquette leaves the briquetting machine, and as a result of a sharp decrease in temperature in contact with air, lignin hardens, which forms the mechanical properties of the formed product.

The quality of the formed briquettes is also affected by the humidity of the raw material. In the general case, this value should be in the range of 7$14 \%[6,8,9]$. At higher humidity, the internal water pressure that occurs during the pressing of raw materials will not allow the formation of quality briquettes and will lead to the stratification of briquettes.

The main goal of the article was to determine the calorific values of dried alcohol distillery stillage of grain origin for the use as a raw material for solid fuel production.

\section{Experimental}

The object of research was corn alcohol distillery stillage after the centrifugation process, obtained on the production line of SE «Vuzlove distillery» (Vuzlove, Lviv region, Ukraine). To remove moisture from the test material, the alcohol distillery stillage was dried by filtration drying to a constant weight according to the method described elsewhere [1].

To determine the residual moisture content in the dried material, studies were performed according to the method described in the State Standard of Ukraine DSTU EN 14774-2:2013 (Solid biofuels. Determination of moisture content).

The ash content of the investigated raw materials was also determined according to the requirements of the State Standard of Ukraine DSTU ISO 18122:2017 (Solid biofuels. Method for determining the ash content).

According to the method of the State Standard of Ukraine DSTU EN 14918:2016 (EN 14918: 2009, IDT. Solid biofuels), the calorific values of dried alcohol corn distillery stillage were determined. Calorimetric studies were carried out using a precision combustion calorimeter B-08-MA with an isothermal shell $( \pm 0.003 \mathrm{~K})$ and a static calorimetric bomb. The energy equivalent of the calorimetric system $(\mathrm{W}=10348 \pm 10 \mathrm{~J} / \mathrm{V})$ was determined with an accuracy of $\pm 0.09 \%$ by burning the reference benzoic acid grade $\mathrm{K}-1$, the content of the main component of which reached $99.995 \pm 0.01 \mathrm{~mol} \%$. The heat of combustion of benzoic acid, considering the Jessup factor, was $-26434.4 \mathrm{~J} / \mathrm{g}$.

Alcohol distillery stillage samples were incinerated in terylene ampoules. Terylene also serves as auxiliary material, as the ignition of the sample occurred simultaneously over the entire surface, which encourages an increase in temperature in the combustion zone and increases the completeness of combustion of the sample. The terylene ampoule was tied with cotton thread and placed in a platinum cup. Ignition of the sample during the experiment was initiated by the discharge of capacitors through a platinum wire, which ignited the cotton thread. The initial pressure of oxygen previously purified from combustible impurities, carbon dioxide and water was $32 \mathrm{kPa}$, and the initial temperature of the main period in all experiments was $298 \mathrm{~K}$. Determination of calorific value was carried out according to Eq. (1).

$\mathrm{Q}=\left(\mathrm{W} \Delta \mathrm{T}-\mathrm{q}_{\text {thread }}-\mathrm{q}_{\text {ampoule }}-\mathrm{q}_{\mathrm{HNO}_{3}}+\mathrm{q}_{\text {soot }}\right) / \mathrm{m}$,

where $\mathrm{W}$ is the energy equivalent of the calorimetric system; $m$ is the mass of the substance that burned during the experiment; $\mathrm{q}_{\mathrm{thread}}, \mathrm{q}_{\text {ampoule }}$, $\mathrm{q}_{\mathrm{HNO}_{3}}, \mathrm{q}_{\text {soot }}$ are the amount of energy released during the combustion of cotton thread $(16704.2 \mathrm{~J} / \mathrm{g})$, terylene ampoule $(22944.2 \mathrm{~J} / \mathrm{g})$, the formation of a solution of nitric acid $(59 \mathrm{~J} / \mathrm{g})$ and soot formed $(32800 \mathrm{~J} / \mathrm{g})$, respectively; $\Delta \mathrm{T}$ is true temperature rises in the calorimetric experiment.

The dried alcohol distillery stillage was pressed in a $\mathrm{P} 474 \mathrm{~A}$ hydraulic press at a pressure of $100 \mathrm{kgf} / \mathrm{cm}^{2}$ and a temperature of $150^{\circ} \mathrm{C}$ for $60 \mathrm{~s}$, $120 \mathrm{~s}$ and $180 \mathrm{~s}$ to obtain prototypes of solid fuel briquettes.

\section{Results and discussion}

The average humidity of the dried alcohol corn distillery stillage (Fig. 1) was $\sim 3$ wt.\% [2].

Determination of the ash content of the studied samples was performed at a temperature of $400^{\circ} \mathrm{C}$ according to the method mentioned above. The results of experimental studies are presented in Table 1, the average ash content of the tested samples of dried corn distillery stillage being $2.1 \mathrm{wt} . \%$.

Table 1

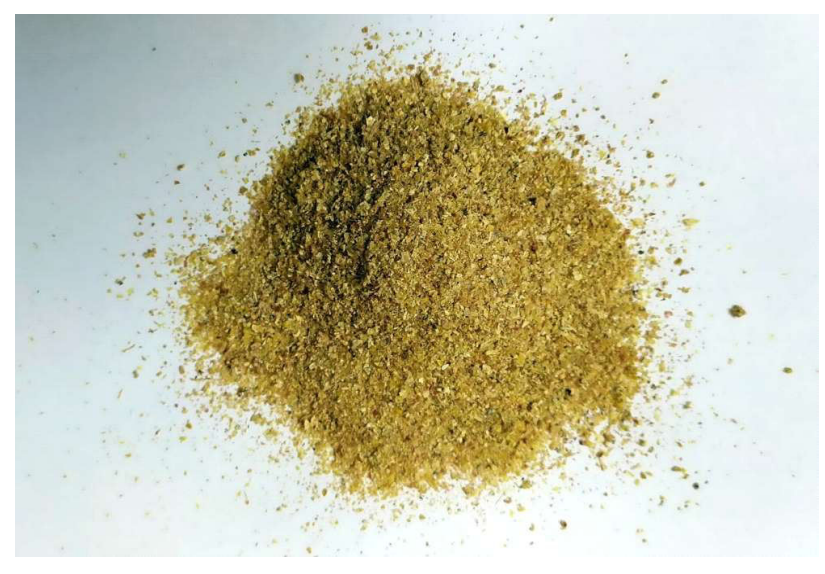

Fig. 1. The dried alcohol corn distillery stillage 
The results of experimental determination of ash content

\begin{tabular}{c|c}
\hline Sample No. & Ash content, wt.\% \\
\hline 1 & 2.8 \\
\hline 2 & 2.8 \\
\hline 3 & 2.1 \\
\hline 4 & 2.0 \\
\hline 5 & 2.0 \\
\hline 6 & 1.4 \\
\hline 7 & 1.6 \\
\hline average & $2.1 \%$ \\
\hline
\end{tabular}

After that, it was experimentally determined the calorific value of dried alcohol corn distillery stillage according to the calorimetry of combustion given in Table 2, that was $19545 \mathrm{~kJ} / \mathrm{kg}(4672 \mathrm{kcal} / \mathrm{kg})$ in average.

For comparison, the values of ash and calorific value of miscanthus and energy willow are given in Table 3, as they are widely used to produce solid fuel briquettes [10].

The obtained value of calorific value of the investigated material slightly exceeds the value of analogs, which indicates a theoretically higher efficiency of solid fuel briquettes from alcohol distillery stillage and might solve the problem of utilization large volumes of its industrial waste. The results of measuring the calorific value of dried alcohol corn distillery stillage showed the prospects and efficiency of its use for the manufacture of solid fuel briquettes. In view of this, it was necessary to conduct further research on the briquettes making.

Let us note that the made pellets must possess a number of certain properties for their subsequent use and burning. For example, according to the German standard DIN 51731, pellets must meet the following parameters: certain geometric dimensions, density $\left(<1.2 \mathrm{~kg} / \mathrm{dm}^{3}\right)$, moisture content $(<12 \%)$, ash content $(<1.5 \%)$, calorific value $(3705-4661$ $\mathrm{kcal} / \mathrm{kg}$ ) and the specified content of certain chemical elements ( $\mathrm{N}, \mathrm{S}, \mathrm{Cl}$, etc.) [11]. There are also many other standards for the pellets in European countries. Compliance with the existing requirements for solid fuel briquettes and pellets in the manufacture regulates the efficiency and safety of their use.

Piston, screw and hydraulic presses are most often used in the industry for the production of solid fuel briquettes. With the help of hydraulic presses, briquettes usually are produced in the form of parallelepipeds, the shape of which is in great demand. Pressing on these devices is carried out cyclically. The raw material is loaded into the matrix, after which the briquette is formed using a punch. After a set pressing time, the briquette leaves the mold with the help of ejectors, and the cycle is repeated again $[6,12]$.

A P474A hydraulic press machine was used for the experiments. Solid fuel in the form of briquettes was prepared from corn alcohol distillery stillage, dried to the moisture content of $\sim 7 \%$ according to the recommendations $[6,8,9]$. The dried alcohol

The results of experimental determination of calorific value according to the calorimetry of combustion

\begin{tabular}{|c|c|c|c|c|c|c|c|c|}
\hline \multirow{2}{*}{ Test No. } & \multirow{2}{*}{$\mathrm{m}, \mathrm{g}$} & \multirow{2}{*}{$\Delta \mathrm{T}, \mathrm{V}$} & \multirow{2}{*}{$\mathrm{q}_{\text {thread }}, \mathrm{J}$} & \multirow{2}{*}{$\mathrm{q}_{\text {ampoule }}, \mathrm{J}$} & \multirow{2}{*}{$\mathrm{q}_{\mathrm{HNO}_{3}}, \mathrm{~J}$} & \multirow{2}{*}{$\mathrm{q}_{\text {soot }}, \mathrm{J}$} & \multicolumn{2}{|c|}{$Q$} \\
\hline & & & & & & & $\mathrm{kJ} / \mathrm{kg}$ & $\mathrm{kcal} / \mathrm{kg}$ \\
\hline 1 & 0.320315 & 0.71478 & 1031.7 & 115.3 & 8.3 & 28.4 & 19573 & 4678 \\
\hline 2 & 0.41836 & 0.92945 & 1364.4 & 109.5 & 11.8 & 32.8 & 19517 & 4665 \\
\hline average & & & & & & & 19545 & 4672 \\
\hline
\end{tabular}

Table 3

The calorific value of dried distillery stillage and widely used plants for solid fuel production

\begin{tabular}{l|c|c|c}
\hline \multirow{2}{*}{ Parameter } & \multicolumn{3}{|c}{ Value } \\
\cline { 2 - 4 } & dried corn distillery stillage & energy willow & miscanthus \\
\hline Ash content, wt.\% & 2.1 & $\approx 1$ & $\approx 2.2$ \\
\hline Calorific value, $\mathrm{kJ} / \mathrm{kg}$ & 19545 & $\approx 17600$ & $\approx 17500$ \\
\hline
\end{tabular}

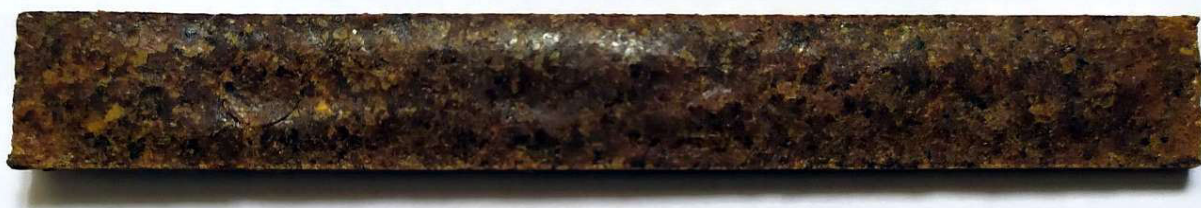

Fig. 2. Test sample of solid fuel from corn alcohol distillery stillage after pressing for $60 \mathrm{~s}$ (sample 1) 
The results of experimental determination of higher calorific value according to the calorimetry of combustion

\begin{tabular}{|c|c|c|c|c|c|c|c|}
\hline \multirow{2}{*}{$\mathrm{m}, \mathrm{g}$} & \multirow{2}{*}{$\Delta \mathrm{T}, \mathrm{V}$} & \multirow{2}{*}{$\mathrm{q}_{\text {тер амп }}, \mathrm{J}$} & \multirow{2}{*}{$\mathrm{q}_{\mathrm{H}}, \mathrm{J}$} & \multirow{2}{*}{$\mathrm{q}_{\mathrm{HNO}_{3}}, \mathrm{~J}$} & \multirow{2}{*}{$\mathrm{q}_{\mathrm{c}}, \mathrm{J}$} & \multicolumn{2}{|c|}{$\mathrm{Q}$} \\
\hline & & & & & & $\mathrm{kJ} / \mathrm{kg}$ & $\mathrm{kcal} / \mathrm{kg}$ \\
\hline \multicolumn{8}{|c|}{ Sample $1\left(150^{0} \mathrm{C}, 60 \mathrm{~s}, 100 \mathrm{kgf} / \mathrm{cm}^{2}\right)$} \\
\hline 0.53400 & 1.25163 & 904.0 & 134.5 & 14.8 & 65.6 & 22405 & 5354 \\
\hline 0.52670 & 1.26037 & 1122.0 & 76.8 & 15.9 & 44.3 & 22540 & 5387 \\
\hline 0.55335 & 1.19907 & - & 121.9 & 19.8 & 123.0 & 22390 & 5351 \\
\hline \multicolumn{6}{|c|}{ Average value } & 22445 & 5364 \\
\hline \multicolumn{8}{|c|}{ Sample $2\left(150^{\circ} \mathrm{C}, 120 \mathrm{~s}, 100 \mathrm{kgf} / \mathrm{cm}^{2}\right)$} \\
\hline 0.38925 & 0.90192 & - & 92.7 & 14.8 & 95.1 & 23945 & 5723 \\
\hline 0.35283 & 0.82550 & - & 103.6 & 7.7 & 91.8 & 24155 & 5773 \\
\hline 0.47070 & 1.08325 & - & 89.4 & 12.4 & 190.2 & 24002 & 5736 \\
\hline \multicolumn{6}{|c|}{ Average value } & 24034 & 5744 \\
\hline \multicolumn{8}{|c|}{ Sample $3\left(150^{\circ} \mathrm{C}, 180 \mathrm{~s}, 100 \mathrm{kgf} / \mathrm{cm}^{2}\right)$} \\
\hline 0.24217 & 0.63235 & - & 120.8 & 7.7 & 45.9 & 26679 & 6376 \\
\hline 0.25820 & 0.66858 & - & 107.7 & 7.4 & 41.3 & 26509 & 6336 \\
\hline \multicolumn{6}{|c|}{ Average value } & 26594 & 6356 \\
\hline
\end{tabular}

distillery stillage was pressed at a pressure of 100 $\mathrm{kgf} / \mathrm{cm}^{2}$ and a mold temperature of $150^{\circ} \mathrm{C}$ for $60 \mathrm{~s}$ (sample 1), $120 \mathrm{~s}$ (sample 2) and $180 \mathrm{~s}$ (sample 3). The example of the obtained result is shown in Fig. 2.

The addition of binders in this method of preparing briquettes from the alcohol distillery stillage is not required. The cooled solid fuel is ready for use. It should be noted that a lower pressure was used for pressing than that given in recommendation [7].

The calorific value of the obtained briquettes was studied according to the method described above (Table 4).

In all samples, the humidity was about $1 \mathrm{wt} . \%$. The ash content in the obtained briquettes is given in Table 5 .

Table 5

The results of experimental determination of ash content

\begin{tabular}{c|c}
\hline Sample No. & Average ash content, wt.\% \\
\hline 1 & $0.6-1.1$ \\
\hline 2 & $1.2-1.6$ \\
\hline 3 & $0.8-1.0$ \\
\hline
\end{tabular}

As can be seen from Tables 2 and 4 , the calorific value of briquetted fuel is slightly higher than the value of unformed dried raw materials; this is most likely due to an increase in the density of the resulting briquette during pressing at elevated temperatures and additional moisture loss.

As for the ash values of the obtained briquette samples, there are no regularities with their determined calorific value. However, it is noticeable that as the pressing time of the sample and temperature increases, the average value of calorific value increases too, which may also be associated with increasing the density and additional drying of the briquette during pressing. This issue requires additional research.

It should be noted that the sample 3 was visually fired after pressing, which indicates the critical value of the residence time in the mold $180 \mathrm{~s}$ at a temperature of $150^{\circ} \mathrm{C}$ and, accordingly, the need to find the optimal residence time of raw materials in the mold and the optimal pressing temperature.

In addition, the use of corn alcohol distillery stillage for solid fuel, which has not passed the drying stage (moisture content of the samples of $\sim 66 \mathrm{wt} . \%$ ), negatively affects the solid form of the briquette and its mechanical strength.

\section{Conclusions}

Thus, an alternative solid fuel was prepared from dried corn alcohol distillery stillage, which is characterized by high calorific value, low ash content, and environmental friendliness and can be used both in solid form (Fig. 2) and in dried form without form (Fig. 1). The average value of the highest calorific value of the dried alcohol distillery stillage is $19545 \mathrm{~kJ} / \mathrm{kg}$, and the corresponding value of solid fuel briquettes made from it is in the range from 22445 to $26594 \mathrm{~kJ} / \mathrm{kg}$. The obtained values, together with low ash content, are close to the existing standards and slightly exceed the indicators of crops that are now widely used to obtain solid fuel briquettes (miscanthus and energy willow).

The proposed method of manufacture of solid fuel is not only simple in technological implementation, but also allows ensuring the utilization of alcohol distillery stillage and the rational use of secondary raw materials of alcohol production. 
Alternative solid fuels from alcohol distillery stillage can further enhance the environmental situation by replacing traditional fuel resources, wood in particular, and the absence of large amounts of harmful emissions.

The obtained results testify to the prospects of further research of this alternative solid fuel, aimed at finding the optimal conditions for the formation of solid form, mechanical strength, etc.

\section{REFERENCES}

1. Research into kinetics of filtration drying of alcohol distillery stillage / Ivashchuk O.S., Atamanyuk V.M., Gnativ Z.Ya., Chyzhovych R.A., Zherebetskyi R.R. // Voprosy Khimii i Khimicheskoi Tekhnologii. - 2021. - No. 4. - P.58-65.

2. Research of the calorific value of dried alcohol distillery stillage / Ivashchuk O.S., Atamanyuk V.M., Chyzhovych R.A., Kuzminchuk T.A., Zherebetskyi R.R., Kiiaieva S.S. // Proc. 3rd Int. Sci. Conf. «Chemical Technology and Engineering». - Lviv, Ukraine. - June 21-24, 2021. - P.200-201.

3. Kinetyka filtratsiinogo sushinnya podribnenogo miskantusa / Atamanyuk V.M., Mosyuk M.I., Ivashchuk O.S., Zaharkiv O.V. // Nauk. Visn. Nats. Lisotekhn. Univ. Ukrayiny. - 2016. - Vol.26. - No. 8. - P.257-264.

4. Modeling of internal diffusion mass transfer during filtration drying of capillary-porous material / Gnativ Z.Ya., Ivashchuk O.S., Hrynchuk Yu.M., Reutskyi V.V., Koval I.Z., Vashkurak Yu.Z. // Math. Model. Comput. - 2020. - Vol.7. No. 1. - P.22-28.

5. Gangil S., Bhargav V.K. Influences of binderless briquetting stresses on intrinsic bioconstituents of rice straw based solid biofuel // Renew. Energy. - 2019. - Vol.133. - P.462-469.

6. Doslidzhennya protsesu formuvannya palyvnykh bryketiv iz roslynnoyi syrovyny ta vyznachennya yikh kharakterystyk / Kindzera D.P., Atamanyuk V.M., Hosovskyi R.R., Motil I.M. // Nauk. Visn. Nats. Lisotekhn. Univ. Ukrayiny. -. 2013. - Vol.23. - No. 17. - P.138-146.

7. Malovanyi M.S., Bat' R.Y. Granulyuvannya palyvnykh materialiv // East. Eur. J. Enterprise Technol. - 2011. - Vol.3/8. - No. 51. - P.8-12.

8. Determination of particle size and distribution through image-based macroscopic analysis of the structure of biomass briquettes / Chaloupkova V., Ivanova T., Ekrt O., Kabutey A., Hera D. // Energies. - 2018. - Vol.11. - Art. No. 331.

9. Manziy S.O., Ferents O.B. Porivnyalni kharakterystyky granuliovanogo ta bryketovanogo biopalyva // Nauk. Visn. Nats. Lisotekhn. Univ. Ukrayiny. - 2010. - Vol.20. - No. 3. - P.8890.

10. Energetychni roslyny yak alternatyva tradytsiinym vydam palyva / Khivrych O.B., Kvak V.M., Kas'kiv V.V., Mamajsur V.V., Makarenko A.S. // Agrobiologiya. - 2011. - Vol.6. -P.153-156.
11. Garcia-Maraver A., Popov V., Zamorano M. A review of European standards for pellet quality // Renew. Energy. 2011. - Vol.36. - P. 3537-3540.

12. Hanzhenco O.M. Tekhnologiya vyrobnytsva tverdogo biopalyva z miskantusu // Bioenergetyka. - 2015. - Vol.2. P.13-17.

Received 02.11.2021

\section{ВИГОТОВЛЕННЯ АЛЬТЕРНАТИВНОГО ТВЕРДОГО ПАЛИВА ІЗ ЗЕРНОВОЇ ПІСЛЯСПИРТОВОЇ БАРДИ}

\section{О.С. Івацук, В.М. Атаманюк, Р.А. Чижович, С.С. Кіяєва,} Р.P. Жеребецький, І.Б. Собечко

Описано виготовлення альтернативного твердого палива із кукурудзяної післяспиртової барди - відходів спиртової промисловості. Охарактеризовано теплотворні характеристики осушеної післяспиртової барди та дослідних брикетів, виготовлених з неї методом пресування за підвищеного тиску та температури. Визначено, що середнє значення вищої теплотворної здатності осушеної післяспиртової барди становить 19545 кДж/кг, а виготовлених брикетів - в межах від 22445 до 26594 кДж/кг. Одержані значення теплотворної здатності перевищують показники аналогів, що широко використовуються для виготовлення альтернативного твердого палива - міскантусу та енергетичної верби. Одержане з кукурудзяної післяспиртової барди тверде паливо можна використовувати як у ствердлій формі, так і в сухому вигляді. Запропонований спосіб одержання твердого палива дозволяє забезпечити додаткову утилізацію післяспиртової барди та раціональне використання вторинної сировини спиртового виробництва.

Ключові слова: післяспиртова барда, вторинна рослинна сировина, тверде паливо, брикети, теплотворні характеристики.

\section{PREPARATION OF AN ALTERNATE SOLID FUEL FROM ALCOHOL DISTILLERY STILLAGE}

O.S. Ivashchuk *, V.M. Atamanyuk, R.A. Chyzhovych, S.S. Kiiaieva, R.R. Zherebetskyi, I.B. Sobechko

Lviv Polytechnic National University, Lviv, Ukraine

* e-mail: oleksandr.s.ivashchuk@Ipnu.ua

The article describes preparation of an alternative solid fuel from corn alcohol distillery stillage, which is the waste of the alcohol industry. We determined the calorific values of the dried alcohol distillery stillage and experimental briquettes, which were made of it by pressing at high pressure and temperature. The average value of the higher calorific value of the dried alcohol distillery stillage is $19545 \mathrm{~kJ} \mathrm{~kg}^{-1}$, while this value for the produced briquettes is in the range of 22445 to $26594 \mathrm{~kJ} \mathrm{~kg}^{-1}$. The established calorific values exceed those of analogues, which are widely used for the producing of alternative solid fuels (miscanthus and energy willow). Solid fuel prepared from corn alcohol distillery stillage can be used both in a solid form and in a dried one. The proposed method for preparation of the solid fuel allows providing additional utilization of alcohol distillery stillage and rational use of secondary raw materials of alcohol production.

Keywords: alcohol distillery stillage; secondary raw materials; solid fuel; briquette; calorific value. 


\section{REFERENCES}

1. Ivashchuk OS, Atamanyuk VM, Gnativ ZYa, Chyzhovych RA, Zherebetskyi RR. Research into kinetics of filtration drying of alcohol distillery stillage. Voprosy Khimii $i$ Khimicheskoi Tekhnologii. 2021; (4): 58-65.

doi: 10.32434/0321-4095-2021-137-4-58-65.

2. Ivashchuk OS, Atamanyuk VM, Chyzhovych RA, Kuzminchuk TA, Zherebetskyi RR, Kiiaieva SS. Research of the calorific value of dried alcohol distillery stillage. Proceedings of the $3^{\text {rd }}$ International Scientific Conference "Chemical Technology and Engineering». June 21-24, 2021; Lviv, Ukraine. Lviv: Lviv Polytechnic National University; 2021. p. 200-201. doi: $10.23939 /$ cte2021.01.200.

3. Atamanyuk VM, Mosyuk MI, Ivashchuk OS, Zaharkiv OV. Kinetyka filtratsiinogo sushinnya podribnenogo miskantusa [Kinetics of filtration drying of crushed miscanthus]. Naukovyi Visnyk Natsionalnogo Lisotekhnichnogo Universytetu Ukrayiny. 2016; 26(8): 257-264. (in Ukrainian). doi: 10.15421/40260840.

4. Gnativ ZY, Ivashchuk OS, Hrynchuk YM, Reutskyi VV, Koval IZ, Vashkurak YZ. Modeling of internal diffusion mass transfer during filtration drying of capillary-porous material. Math Model Comput. 2020; 7(1): 22-28. doi: 10.23939/mmc2020.01.022.

5. Gangil S, Bhargav VK. Influences of binderless briquetting stresses on intrinsic bioconstituents of rice straw based solid biofuel. Renew Energy. 2019; 133: 462-469.

doi: $10.1016 /$ j.renene.2018.10.033.
6. Kindzera DP, Atamanyuk VM, Hosovskyi RR, Motil IM. Doslidzhennya protsesu formuvannya palyvnykh bryketiv iz roslynnoyi syrovyny ta vyznachennya yikh kharakterystyk [Research of the process of formation of fuel briquettes from vegetable raw materials and determination of their characteristics]. Naukovyi Visnyk Natsionalnogo Lisotekhnichnogo Universytetu Ukrayiny. 2013; 23(17): 138-146. (in Ukrainian).

7. Malovanyi MS, Bat' RY. Granulyuvannja palyvnykh materialiv [Granulation of fuels]. East Eur J Enterprise Technol. 2011; 3/8(51): 8-12. (in Ukrainian).

8. Chaloupkova V, Ivanova T, Ekrt O, Kabutey A, Hera D. Determination of particle size and distribution through imagebased macroscopic analysis of the structure of biomass briquettes. Energies. 2018; 11: 331. doi: 10.3390/en11020331.

9. Manziy SO, Ferents OB. Porivnyalni kharakterystyky granuliovanogo ta bryketovanogo biopalyva [Comparative characteristics of granulated and briquetted biofuels]. Naukovyi Visnyk Natsionalnogo Lisotekhnichnogo Universytetu Ukrayiny. 2010; 20(3): 88-90. (in Ukrainian).

10. Khivrych OB, Kvak VM, Kas'kiv VV, Mamajsur VV, Makarenko AS. Energetychni roslyny yak alternatyva tradytsiinym vydam palyva [Energy plants as an alternative to traditional fuels]. Agrobiologiya. 2011; 6: 153-156. (in Ukrainian).

11. Garcia-Maraver A, Popov V, Zamorano M. A review of European standards for pellet quality. Renew Energy. 2011; 36: 3537-3540. doi: 10.1016/j.renene.2011.05.013.

12. Hanzhenco OM. Tekhnologiya vyrobnytsva tverdogo biopalyva $\mathrm{z}$ miskantusu [Technology of solid biofuel production from miscanthus]. Bioenergetyka. 2015; 2: 13-17. (in Ukrainian). 